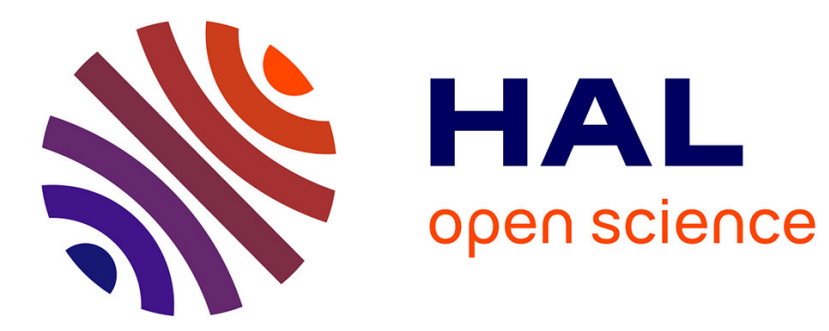

\title{
Conditions of Development of a Product Ecolabel
}

Alain Nadai

\section{To cite this version:}

Alain Nadai. Conditions of Development of a Product Ecolabel. European Environment, 1999, 9 (5), pp.202-211. halshs-00159961

\section{HAL Id: halshs-00159961 https://shs.hal.science/halshs-00159961}

Submitted on 4 Jul 2007

HAL is a multi-disciplinary open access archive for the deposit and dissemination of scientific research documents, whether they are published or not. The documents may come from teaching and research institutions in France or abroad, or from public or private research centers.
L'archive ouverte pluridisciplinaire HAL, est destinée au dépôt et à la diffusion de documents scientifiques de niveau recherche, publiés ou non, émanant des établissements d'enseignement et de recherche français ou étrangers, des laboratoires publics ou privés. 


\title{
Conditions of Development of a Product Ecolabel
}

\author{
Alain Nadaï \\ Center for the Study and Improvement of Regulations \\ Department of Engineering and Public Policy \\ Carnegie Mellon University \\ 129, Baker Hall \\ Pittsburgh, PA 15213-3890 \\ USA \\ tél: 14122688099 \\ fax: 14122683757 \\ nadai@andrew.cmu.edu
}

(Draft version, do not quote, please refer to the published version for quoting ${ }^{1}$ )

${ }^{1}$ NADAI. A. (1999), "Conditions of Development of a Product Ecolabel“, European Environment, Special Issue on Integrated Product Policy. 


\begin{abstract}
Since the early 1990s, national ecolabelling programmes have proliferated worldwide. The European Union (EU) implemented such a regional progam in 1991. This decision was part of a broader orientation towards Integrated Product Policy approach in the EU. Since 1991, the development of European ecolabels has been slow and difficult. This paper examines industrial strategies vis-à-vis the EU ecolabel in order to understand the problems faced by the regulator in the development of this ecolabel.

The first part of the paper defines and uses the concept of credence good in order to argue that the consumer cannot assess the ecolabel. Based on the examination of the development of the European ecolabel, the second part points out three variables that seem to influence the development of product eco-labels : i) the type of industry (i.e. the degree of heterogeneity between the sets of products sold by the different firms); ii) the threat of direct governmental regulation on the environmental quality of the product; and, iii) the magnitude of the final demand for a green variant of the product. The paper concludes with a discussion of on policy implications for policy makers interested in considering or promoting the use of ecolabels.
\end{abstract}

Keywords: quality, eco-labeling, voluntary environmental regulation.

\title{
JEL classification: Q 28, D43
}




\section{INTRODUCTION}

Since the beginning of the 1990s, product ecolabelling programmes have proliferated worldwide. There are now about twenty national ecolabelling schemes in the OECD and countries such as China, Brazil and India are considering the implementation of national ecolabelling programmes. In 1992, the European Union (EU) issued a regulatory framework for a regional scheme.

The ecolabelling process includes two phases. The phase of negotiation consists of a negotiation between the firms and the regulator in order to set up the ecolabelling criteria. These criteria typically consist of a list of maximum thresholds of polluting emissions, which have not to be surpassed by a product in order to be eligible for the ecolabel. These thresholds generally relate to the polluting emissions released by the product throughout its whole life cycle. A market phase follows. During this phase, products which meet the criteria can be labelled as doing so by the firms and compete in the marketplace.

Ecolabels offer firms the opportunity to signal to consumers which products are more respectful to the natural environment than their substitutes. For regulatory authorities they are a means to encourage firms to improve the environmental quality of their products - i.e. to make environmental innovations. In the European context, the development of product ecolabelling is part of the Integrated Product Policy approach ${ }^{2}$. Regulators expect that firms will i) innovate during the market phase in order to meet the criteria, ii) ecolabel their product, and iii) capture, thanks to the signaling, benefit from consumers willingness to pay for a clean natural environment.

However, the proliferation of ecolabelling schemes does not guarantee the effective development of product ecolabels. First, the decision to participate in the EU ecolabelling program is voluntary and firms may decide

\footnotetext{
${ }^{2}$ This point is debated by some analysts. Indeed, the European product ecolabelling scheme has been developed in the need to find new ways of addressing the multi-dimensionality of environmental impacts. As a matter of fact, this took place prior to EU Commission's explicit interest in, and discourse about IPP policies. Some analysts argue thus, that considering the ecolabel as part of IPP approach is an ex-post rationalisation.
} 
not to participate. In addition, the experiences to date with the development of ecolabels show that in some cases firms actively oppose their development. These firms try to block agreement on the criteria or, if these criteria are nonetheless adopted by the regulator, they form a cartel to avoid using the ecolabels on their products. While such opposition can hamper the development of the ecolabels, as it did in the European Union, its cause has not been clearly analysed.

This paper tackles the question of why firms do or do not choose to participate in order to identify conditions that can lead to the better development of product ecolabels.

One main obstacle in the development of the European ecolabel since 1992 has been the difficulty of reaching a compromise on the criteria during the negotiation phase. The following analysis shows that firms' self-interest vis-a-vis the implementation of an ecolabel in their market determines the possibility of such a compromise.

In order to understand the origin of this problem, we go back to considerations about the notion of product quality. Using the micro-economic concept of "credence good", we demonstrate that the ecolabel cannot be assessed by the consumer even after purchase. We show that developing the ecolabelling criteria requires an expertise about the product and its environmental impact, and that this expertise is not within the reach of the consumers. They cannot assess the relevance of the ecolabelling criteria and uncertainty remains regarding the environmental quality of the products. As a consequence, the agents in charge of devising the criteria may manipulate this expertise in order to obtain criteria which allow them to increase their market profits, as compared to the pre-ecolabelling situation. This margin of manoeuvre and the diverging self-interests explain the difficulties faced by the regulators during the negotiation phase and in the development of the ecolabels.

The first part of the paper defines and uses the concept of credence good in order to argue that the consumer cannot assess the ecolabel. Based on the examination of the development of the European ecolabel, the second part points out three variables that seem to determine the outcome of the negotiation phase. In the 
third part, we derive some practical implications regarding the conditions for the successful development of a product ecolabel.

\section{THE ECOLABEL CANNOT BE ASSESSED BY CONSUMERS}

We will first demonstrate that the environmental quality of a product is a peculiar kind of credence good: one that cannot be assessed by the final consumer even if he is perfectly informed about the polluting emissions per unit of product (i.e. unitary polluting emissions). In order to demonstrate this, we examine the information which is necessary for devising the criteria. The following considerations are drawn from two cases-studies: the negotiation of the European ecolabelling criteria for 'Indoor paints and varnishes' (Nadaï, 1996a) and the negotiation of the European ecolabelling criteria for 'Detergent products’ (Nadaï, 1996b, 1998a).

The devising of the criteria in the EU is made up of two phases: i) the regulator makes a proposal, and ii) negotiation follow between industry and the regulator.

A state of the art on the environmental impact of the product allows the regulator to elaborate a first proposal of criteria. In the case of the European ecolabel, this phase is undertaken by a leading member State, which is generally designated by the EU Commission. This phase proceeds as follows. An inventory of polluting emissions per unit of product is undertaken. The total quantity of each emission is then calculated by multiplying unitary emissions times the product market volume. Finally, scientific knowledge about the physical and chemical reactions of the natural environment to these emissions is considered by experts in order to assess the contribution of the product to major environmental impacts such as greenhouse effect, acid rain, water pollution, air pollution, etc.

A negotiation follows. It modifies the criteria: i) by negotiating requirements (i.e. maximum quantities per unit of product) for each polluting emission; and, ii) by weighing out the different environmental impacts, in order to aggregate the criteria in a single index of environmental quality. This phase is based on a collective negotiation between the economic agents who are directly concerned by the market of the product, such as the producers and the regulator. 
As a result, the expertise required for the definition of the ecolabelling criteria is based on knowledge about the natural environment and the product life-cycle, which is shared between the actors involved on the ecolabelling process, and on a compromise between the actors concerned by the specific product market. This environmental expertise is thus specific to each group of products so that the consumer purchases this expertise when purchasing an ecolabeled product.

As this is a typical feature of credence goods, it is interesting to use this notion in order to develop our argument. Common instances of credence goods are medical services (e.g. a surgery), car-repair services, etc. They are traditionally defined by the fact that the seller is also the expert who advises the consumer on which quality to purchase in order to better fit his demand, while the consumer has only an imperfect ability to check this advice. Micro-economic models (Darby and Karni 1973; Wolinsky, 1995) show that in such a case the seller may manipulate the expertise in order to increase his profits. This fraud is only limited by the threat of consumers leaving a fraudulent expert. This may happen if consumers can buy an alternative diagnosis from another expert or if they are able to detect the fraud on their own, let say by experiencing the good after purchase. The probability of these events acts as a threat to all sellers and limits their fraud. The point is that consumers assess the quality of the good by its consequences (e.g. the symptom rather than the intrinsic characteristics of the surgery that was sold to him) and that the possibility of assessing them after purchase is a pre-requisite for consumers to limit seller's fraud.

This scheme can be applied, point by point, to the environmental quality of the product.-

Within such a perspective, the environmental impact of the product becomes an analogue of the patient's disease or symptom (i.e. to be cured or reduced), whereas the ecolabel becomes an analogue of a medical expertise/prescription (i.e. take this drug, purchase this product). Indeed, based on environmental expertise, the ecolabel advises consumers to purchase a given type of product (i.e. the ecolabeled ones) in order to improve the state of the natural environment (i.e. to increase their own satisfaction/utility). We assume here that consumer derive their utility from the natural environment and that the reduction in the polluting emissions of the product, which is the object of the ecolabel's prescription, is only a means to improve the state of the natural environment. 
As the above-mentioned considerations about credence good make clear, the key question related to the limitation of experts' fraud is whether or not consumers can assess "post-purchase" the satisfaction derived from the consumption of the prescribed good. In the case of the ecolabel, this refers to the possibility of assessing the environmental impact of ecolabeled products.

Our answer to this question is that it is impossible for consumers to assess the environmental impact of a product, even when they are perfectly informed about the product's profile of polluting emissions. This is due to the spatial, temporal and non-exclusion features of most environmental impacts.

Some of these environmental impacts, as for example acid rain in Europe, are global. Their assessment requires an expertise that is not in the reach of consumers. Other impacts, among which the greenhouse effect is a good example, will only be perceptible to consumers many years from now. In such cases, the act of purchasing a product today is concretely disconnected from the occurrence of these impacts: the relevance of the environmental expertise will only be assessable in a long term future, when sanctioning the current sellers or experts will no longer be possible for the consumer. This cognitive gap can only be bridged in a very abstract way, again through an expertise which is not within the reach of consumers. Other environmental impacts are characterised by non-exclusion. They result from the total quantity of polluting emissions generated by the market of a product, so that each consumer can neither exclude the other consumers from the environmental benefits of his/her purchase nor assess his/her own participation in improving of the natural environment (i.e. the participation of his/her own purchase to this improvement).

In other words, having a perfect knowledge of the criteria does not enable consumers to assess the relevance of the ecolabel as regards to the improvement of the natural environment: consumers cannot assess the ecolabel $^{3}$.

\footnotetext{
${ }^{3}$ To be clear, this argument has been developed by considering the limits of utilitarian categories when it comes to the environmental quality of the products. This means that we do not share the utilitarian perspective in this domain. As consumers do purchase green products while not being able to assess the actual environmental impact of their purchase, considerations such as self-identifications or social norms may also underlie their purchasing decision.
} 
This uncertainty gives to both the firms and the regulator a margin of manoeuvre for devising of the ecolabelling criteria. We will now focus on the case of the European ecolabel in order to examine the strategies undertaken by the industrial interest groups during the phase of negotiation of the criteria.

\section{THE DEVELOPMENT OF THE EUROPEAN ECOLABEL}

The state of the different product groups in spring of 1996, that is to say four years after the adoption of the European Ecolabelling regulation, is summarized in Figure 1 (Cf. last page).

The problems which have occurred in the development of the different ecolabels have various origins: divergence of interests between member States; divergence of interests between industrial interest groups within the concerned industry; and, frontal opposition of the whole industry to the devising of any criteria or to the development of the ecolabel on the final market. As a result, the negotiation phase has been very long for most groups of products, often taking from three to four years and delaying the development of the European ecolabel. Without denying the influence of divergences among member States (Nadaï, 1996a, pp31-33), we will focus the analysis on the industrial issues.

A survey of these different product groups and an in-depth analysis of the development of two ecolabels (i.e. detergents, and indoor paints and varnishes) allows us to point out three variables influencing the outcome of the negotiation phase.

\subsection{THE NEGOTIATION PHASE: CONFIGURATIONS AND DETERMINANTS}

Three variables determine the chances of success of the phase of negotiation. They are: the degree of technological heterogeneity of the industry (i.e. the degree of heterogeneity of the environmental profile of the products sold by the different firms); the threat of regulation of the environmental quality of the products; the final demand for an environmental variant of the product. These variables allow us to distinguish (Cf. Fig 2) among: i) situations in which the regulator faces the opposition of the industry in the negotiation of the criteria (situation 1 in Fig 2); ii) situations in which the industry cooperates to design criteria and develop the ecolabel on the market (situation 2 in Fig 2); and, iii) situations in which the industry splits up into two 
strategic groups fighting about the content of the criteria, where the regulator ultimately must choose with which industrial group to cooperate (situation 3 in Fig 2).

The principles leading to the above results are the following ones. The threat of environmental regulation raises a potential cost for the firms. Indeed, if any regulation were to be implemented, firms would bear costs for complying with the new environmental standard. However, firms may hope to reduce this cost by negotiating a minimal standard within the ecolabelling process instead of having to comply with a regulation on product quality. Moreover, in contrast to a classical quality standard, the ecolabel is advertised to the consumers and may increase their willingness to pay for the product. Firms may thus be in a position where they can recover their ecolabel compliance cost through an increase in the product's final demand. This shows that the final demand for an environmental variant of the product and the threat of environmental regulation play similar roles: if both of them are weak, firms will not expect important gains from ecolabelling and the regulator will be faced with firms' indifference or opposition during the negotiation phase (type 1 configuration in Fig.2).

Figure 2: Empirical configurations of the negotiation phase

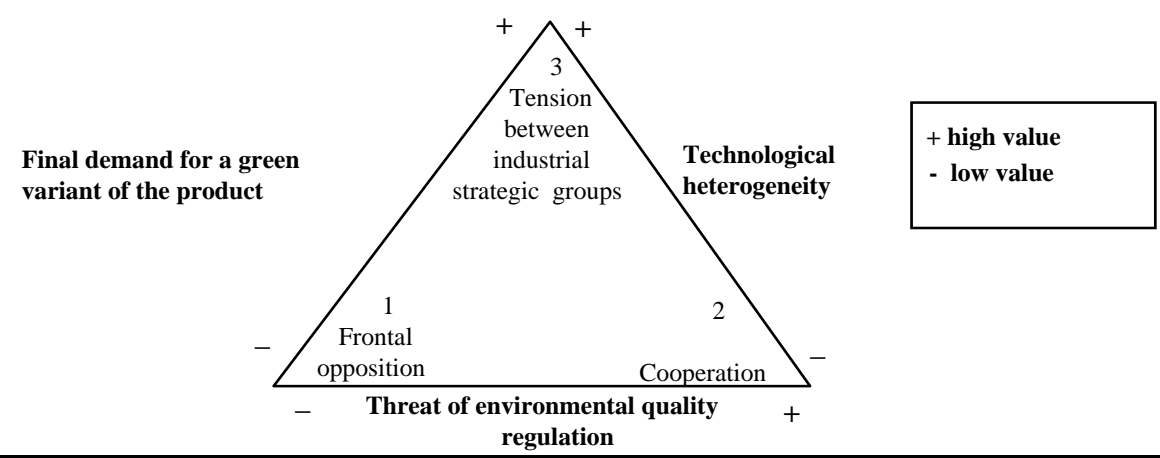

On the other hand, if at least one of these variables takes a high value (strong threat of environmental regulation or important final demand for a green variant of the product), ecolabelling may be a gain for the firms. In such a case, the third variable - the degree of technological heterogeneity of the industry determines the configuration of the negotiation phase. Two polar cases of industry must then be considered. 
When all the firms of an industry sell the same range of products, whatever the content of the criteria, all firms have access to the ecolabel under the same conditions. Therefore, they all have similar concerns with regards to the content of the ecolabelling criteria. The firms' sole problem is to determine which type of criteria will be the most profitable for them all. In such a case, the co-operation of the whole industry may be expected if the ecolabel generates a gain for the firms (type 2 configuration in Fig. 2). Following the logic previously described, this may happen if the final demand for green products is significant or if an environmental regulation is already in the pipeline.

When the industry is made up of firms each selling one product which has a different environmental profile from the products of the other firms, i.e. when products are technologically heterogeneous, the exclusion of a product from the ecolabel is equivalent to the exclusion of a firm: rivalry appears in the negotiation of the ecolabelling criteria, for satisfying one firm's interest will go against the interests of the other firms. If the gain at stake is significant, the industry will split up into strategic groups which will disagree about the content that should be given to the criteria (type 3 configuration in Fig. 2).

\subsection{EMPIRICAL ILLUSTRATION}

A review of several case studies can illustrate the preceding concepts. We review the cases of the detergent; indoor paints and varnishes; hairsprays; and batteries ecolabels.

The confrontation of strategic groups has shaped the negotiation of the detergents criteria at the EU level (Nadaï , 1996 a). The detergent industry split up into two rival strategic groups whose goal was to obtain criteria allowing their respective members to get free access to the ecolabel (i.e., without having to environmentally improve their products). The major detergent producers are members of the Soap and Detergent Industry's European Association (AIS). Small producers developing a green niche on the European Detergent market, such as the well-known Ecover, are members of the European Association of Environmental Detergent Manufacturers (EDMA). These small and medium enterprises (SMEs) created the EDMA during the course of the negotiation of the European detergent criteria (i.e. in 1993) in order to instill representation in this negotiation. All together, the members of this trade association total two to four percent 
of the European detergent market. The result of these two strategic groups'conrfontation has been the adoption of criteria that were not really selective; the criteria did not exclude very many products from the ecolabel. A survey undertaken in this industry at the beginning of the year 1996 (Nadaï , 1996 a, pp53-55) showed that about $50 \%$ of the EU detergent market volume was eligible for the ecolabel. As a matter of comparison, the Commission had advertised a ten-percent selectivity (i.e. ecolabelling criteria allowed ten percent of the products to be awarded the ecolabel) at the end of the negotiation phase (July 1995). The gap between the Commission's belief and the effective selectivity of the criteria was due to two factors:

- The influence of the main detergent manufacturers trade association - the AIS - whose goal in the negotiation phase had been clearly announced at the beginning of the process: AIS asked for a 5\% exclusion rate, which meant allowing $95 \%$ of the detergent products to be eligible for the ecolabel without any improvement of their environmental performance.

- The imperfect information of the Commission: the EU Commission assessed the selectivity of the criteria on the basis of market data which was not up-dated throughout the four years of the negotiation phase.

In the spring of 1997, no firms were interested in ecolabelling their products. The reason for this was that the ecolabel not being selective enough, each firm was expecting to face a lot of followers/competitors if it chose to ecolabel its product. Moreover, the "green" fringe of this industry (mostly small and medium enterprises such as Ecover) thought that such a lax ecolabel could not be credible for the final consumer: they refused to encourage its development and so would not use it on their products. As of February 1, 1999, only one firm was using this label on its product. Interestingly, this firm has typical features of both AIS and EDMA members. On the one hand, it is selling a well-known heavy-duty product, which justifies its AIS membership. On the other hand, it is a marginal producer developping over several years a green-line of products (i.e. Maison Verte) sold in hyper-markets, which could justify an affiliation to EDMA. In 1996, it was the only producer having a market position that made it inclined to apply for the European detergent ecolabel (Nadaï , 1996 b, pp 55-58).

The case of co-operation within the industry and between the industry and the regulator is illustrated by the negotiation of the indoor paints and varnishes ecolabelling criteria. This industry is made up of producers 
each selling the entire range of products. In the EU, this industry is currently under both strong regulatory pressure and strong market pressure for a reduction in the volatile organic compounds (VOC) content of its products. This is especially true regarding glycerophtalic products which contain solvents, as opposed to acrylic products which are water-based. Markets from the northern countries of the EU have already evolved in this direction and the main European producers in this industry consider that, in the near future, such an evolution cannot be avoided in the other EU countries. In the current state of the market in these other countries, water-based paints have lower VOC contents than solvent-based ones but are most frequently advertised as being of lower quality (e.g. less glossy, shorter durability, lower resistance, etc). Water-based products are thus possible short-term candidates for an environmental certification. However, the paint producers are interested in managing the evolution of the market so as not to erase the current market differentiation which allows them to make higher profits on "high quality" products. Qualifying only waterbased products as environmentally beneficial may well contradict and erase this differentiation by opposing “ high ” quality with “ environmental ” quality.

As a matter of fact, the technological characteristics of the high-quality segment will have to be changed in the future and this may be achieved in two different ways. A first possibility is to progressively develop high-quality water-based products and introduce them into the high-quality segment, where they are not present at the current time. A second possibility is to develop solvent-based products with low VOC emissions levels. The so-called "high dry-extract" products, based on a new technology, are good candidates for that. Both routes are in fact possible and could be achieved at the same time if the ecolabel would be based on different sets of criteria for each group of products. The progressive modification of the market which would ensue may then be advantageous for this industry for the following two reasons. First, the new market segmentation would bring into synergy high quality and environmental quality (rather than opposing them if water-based paints were immediately qualified as the sole environmental products). Second, this evolution would homogenize the EU market and allow the producers to exploit economies of scale in production and retailing. 
As a result, the paints and varnishes industry sought to obtain two separate sets of criteria, one for each of the existing market segments, and asked for criteria on solvent-based products that would allow for the eligibility of "high dry-extract" products. Despite strong tensions between the member States during the negotiation phase, a compromise of criteria has been reached. It takes into account the above industrial interest.

In this instance, the main issue for the firms was to use the ecolabel in order to foster an evolution of their market that they all considered as profitable given the ongoing regulatory context and the evolution of the final demand.

Finally, instances of industrial opposition to criteria development (i.e. hairsprays and batteries ecolabels) confirm the role played by the threat of environmental regulation and the final demand for an environmental variant of the product. For example, the EU-ecolabelling criteria proposed by the UKEB (UK ecolabelling board) for hairspray triggered the opposition of the hairspray industry. According to these criteria, pumpsprays would have been eligible for the EU-ecolabel whereas air-sprays would not have been. Hairspray producers attempted to develop pump-sprays several years ago, without any success. They concluded that the market demand for pump-sprays was not significant enough so as to justify this development. As a result, air-sprays do represent the most important part of the EU hairspray market and they would have been disqualified by this ecolabel as compared to pump-sprays. Consequently, the cosmetics industry opposed the UKEB proposal of criteria. The cosmetic industry trade association (COLIPA) decided to block all the other product groups in which it was involved (e.g. cosmetics). As of February 1, 1999 the only criteria that were under development were the shampoos criteria (i.e. the preliminary study had been completed).

Another instance of frontal industrial opposition is illustrated by the ecolabelling process on batteries. The EU Commission appointed France as the member State to lead the process. In 1992, the battery industry refused to collaborate with regulators on the development of ecolabelling criteria for its products. The industry argued that the cost of compliance with such an ecolabel would have been too high if, as proposed by the French authorities, the criteria were to include environmental requirements other than the mercury and cadmium content of batteries. Following the industry's announcement of their position, in 1994, an official threat of regulating the environmental quality of these products by means of a minimal quality standard was 
announced by the French Ministry of the Environment. This forcing action by the government was enough to induce this industry to collaborate on the development of the preliminary study for devising ecolabelling criteria on their products.

\section{CONCLUSION: PRACTICAL IMPLICATIONS AS REGARDS TO THE DEVELOPMENT OF A PRODUCT ECOLABEL}

We have first argued that, albeit product ecolabels share a central property with credence goods - i.e. that of relying on an expertise owned by the seller -, product ecolabels cannot be assessed post-purchase by the consumers, as is the case for credence goods. This gives the sellers room for manipulating the content of the product quality, that is the environmental criteria underlying the definition of the ecolabel. Therefore, the issues at stake and the industrial strategies taking place in the negotiation of these criteria.

We have then emphasize various variables that determined the configuration of this negotiation. This allows us to draw some conclusions as regards policy implications.

If one finds it reasonable to assume that neither industry nor regulators have an interest in spending three to four years negotiating ecolabelling criteria without any success, one can derive a first result: in a configuration of low final demand for an environmental variant of the product and when there is no regulatory pressure for an improvement in the environmental quality of the product, there is little value in engaging in a negotiation on ecolabelling criteria.

In the opposite case - i.e., when either the final demand for an environmental variant of the product or the regulatory pressure for an improvement in the environmental quality of the product are strong - our analysis allows us to shed light on the possible role of the regulator in the ecolabelling process:

If the industry is homogeneous, co-operation between its representatives and the regulator in the devising

of the criteria is likely to emerge. Reaching a compromise of criteria may not be difficult and investing in the production of information about the life-cycle of the product, its polluting emissions, and so on, 
may be worthwhile in order to improve the knowledge about the environmental impacts of the product and the choice of the criteria.

If the industry is heterogeneous, the regulator may have to arbitrate between rival industrial strategic groups. As regards to this case, it is interesting to compare the history of some national ecolabels on detergent products, such as the "White Swan" (i.e. the Nordic Council ecolabel) or the "Blue Angel" (i.e. the German ecolabel), with that of the European ecolabel. Indeed, the early development of the "White Swan " or "Blue Angel” criteria on detergent products was first difficult because of the opposition of the leading detergent producers. The development of these ecolabels has finally been possible because the national authorities in charge of it decided to co-operate with the interested marginal detergent producers and retailers. The leading producers got involved into these ecolabels when they were already well known by the consumers and developed on the final market. Different from this, when developing the European detergent criteria, the German “ Umweltbundesamt” decided to rely on at least one of the leading producers. The goal was to obtain a wider development of the ecolabel on the final market. Yet, this allowed the leading producers interest group to play a prevalent role in the negotiation; it led to the weak selectivity of this ecolabel and to its very low development. In such cases of heterogeneous industry, the regulator should thus pay critical attention to market issues in order to decide which group may give the most chance for the ecolabel to get developed on the final market. 
Figure 1. The European ecolabel: state of the product groups (February 99)

\begin{tabular}{|c|c|c|c|}
\hline Group & MS* & Situation & Main problems faced during the negotiation** \\
\hline Dish washer & UK & $\begin{array}{c}\text { Adopted } \\
\text { (Aug. 93) } \\
\text { Revised } \\
\text { (Jun. 96) } \\
\text { Under } \\
\text { revision in } \\
\text { Feb. 99 }\end{array}$ & $\begin{array}{l}\text { Not utilised by the firms (except one). Criteria do not bring any additional information to the consumers: } \\
\text { no final demand expected for such } \\
\text { an ecolabel. }\end{array}$ \\
\hline Washing machines & UK & $\begin{array}{c}\text { Adopted } \\
\text { (Aug. 93) } \\
\text { Revised } \\
\text { (May 96) } \\
\text { Under } \\
\text { revision in } \\
\text { Feb. 99 } \\
\end{array}$ & $\begin{array}{l}\text { - First criteria not utilised by the firms (except one firm). Criteria do not bring any additional information } \\
\text { to the consumers: no final demand expected for such an ecolabel. } \\
\text { - Criteria under revision in } 1996 .\end{array}$ \\
\hline $\begin{array}{l}\text { Tissue paper } \\
\text { (Kitchen and toilet } \\
\text { paper) }\end{array}$ & DK & $\begin{array}{l}\text { Adopted } \\
\text { (Dec.1994) } \\
\text { Revised } \\
\text { (Jan. 98) }\end{array}$ & $\begin{array}{l}\text { - Differences in production systems from one country to the other : } \\
\text {. UK (recycled fibers), North European countries (virgin fibers, vertically integrated production), other } \\
\text { countries (virgin and recycled, non-integrated production), } \\
\text { - AOX emissions. } \\
\text { - French opposition to the criteria: no functional unit of product taken into account in the definition of the } \\
\text { criteria. }\end{array}$ \\
\hline Soils improvers & UK & $\begin{array}{l}\text { Adopted } \\
\text { (Dec. 94) } \\
\text { Revised } \\
\text { (April 98) }\end{array}$ & None. \\
\hline $\begin{array}{c}\text { Indoor paints and } \\
\text { varnishes }\end{array}$ & F & $\begin{array}{l}\text { Adopted } \\
\text { (Feb.95) } \\
\text { Revised } \\
\text { (Jan. 99) } \\
\end{array}$ & Heterogeneity in the differentiation of the national markets (water/solvent based products) \\
\hline Detergents & $\bar{G}$ & $\begin{array}{l}\text { Adopted } \\
\text { (Feb. 95) } \\
\text { Under } \\
\text { revision in } \\
\text { Feb. } 99\end{array}$ & $\begin{array}{l}\text { - Confrontation of industrial strategic groups: Green SME's / Leading firms. } \\
\text { - Phosphates versus zeolithes: National differences in existing regulations. } \\
\text { - Divergences as regards: ban of ingredients, index of ingredients-toxicity to be taken into account. } \\
\text { - Opposition of the leading firms to a homogenisation of dosage- on the products at the European level. } \\
\text { - Uncertainty as regards to the development of the label on the final market: criteria too lax in order to } \\
\text { retain firms' interest (too much competition on ecolabeled products expected). }\end{array}$ \\
\hline $\begin{array}{c}\text { Single-ended light } \\
\text { bulbs }\end{array}$ & UK & $\begin{array}{l}\text { Adopted } \\
\text { (Dec. 95) } \\
\text { Under } \\
\text { revision in } \\
\text { Feb. } 99 \\
\end{array}$ & $\begin{array}{l}\text { - Definition of the products group (inclusion or not of low-consumption light bulbs) } \\
\text { - Opposition of the industry on the ground of already too high cost of compliance with the current } \\
\text { regulations, in particular industry was opposed to the inclusion of threshold on the mercury content of the } \\
\text { bulbs. }\end{array}$ \\
\hline $\begin{array}{l}\text { Double ended light } \\
\text { bulbs }\end{array}$ & UK & $\begin{array}{l}\text { Adopted } \\
\text { (May 96) } \\
\text { Under } \\
\text { revision in } \\
\text { Feb. 99 } \\
\end{array}$ & Idem. \\
\hline $\begin{array}{c}\text { Refrigerators and } \\
\text { freezers }\end{array}$ & $\bar{I}$ & $\begin{array}{l}\text { Adopted } \\
\text { (Dec. 96) } \\
\text { Under } \\
\text { revision in } \\
\text { Feb. } 99 \\
\end{array}$ & None. \\
\hline Electric batteries & F & $\begin{array}{l}\text { Study } \\
\text { completed } \\
\text { Work } \\
\text { suspended }\end{array}$ & $\begin{array}{l}\text { - Negotiation between the industry and the French authorities in order to decide whether or not to include } \\
\text { the cadmium and mercury contents in the criteria. } \\
\text { - Strong opposition of the industry which considers that the cost of compliance with such an ecolabel } \\
\text { would be too high. Pressures from the French Ministry of the Environment allowed to temporarily } \\
\text { overcome this opposition and complete the preliminary study for devising the criteria. The work has then } \\
\text { been suspended. }\end{array}$ \\
\hline Copying paper & DK & $\begin{array}{l}\text { Adopted } \\
\text { (Aug. 96) } \\
\text { Under } \\
\text { revision in } \\
\text { Feb. 99 } \\
\end{array}$ & $\begin{array}{l}\text { - Idem toilet paper. } \\
\text { - Industrial preference for the Eco-audit scheme (EMAS, effort logic as opposed to performance threshold). } \\
\text { - International trade issue: the definition of sustainability as regards to forest management requires a } \\
\text { political treatment of the question. }\end{array}$ \\
\hline $\begin{array}{c}\text { Bed linen and Tee- } \\
\text { shirts }\end{array}$ & DK & $\begin{array}{l}\text { Adopted } \\
\text { (May 96) }\end{array}$ & $\begin{array}{l}\text { - International trade issue: Is it possible to impose requirements on the conditions of production in non-EU } \\
\text { countries? } \\
\text { - Industry was opposed to restrictions on the use of bleaching agents during the manufacturing process } \\
\text { (causing chlorine release). } \\
\text { - Arbitrage between natural and artificial fibers: this issue led to an extension in the product group (Dec. } \\
\text { 97). Up to 5\% of elastic fibers are now tolerated in ecolabeled products, if it is technically justified. }\end{array}$ \\
\hline $\begin{array}{l}\text { Material for building } \\
\text { insulation }\end{array}$ & DK & $\begin{array}{c}\text { Suspended in } \\
\text { Feb. } 99\end{array}$ & Criteria were under development in 96; reasons for work suspension have not informed. \\
\hline Group & MS* & Situation & Main problems faced during the negotiation** \\
\hline
\end{tabular}




\begin{tabular}{|c|c|c|c|}
\hline $\begin{array}{c}\text { Footwear, } \\
\text { Detergents for } \\
\text { dishwashers, } \\
\text { Textile products, } \\
\text { Personal computers }\end{array}$ & \begin{tabular}{|c|} 
(not \\
inform \\
ed)
\end{tabular} & $\begin{array}{l}\text { Awaiting } \\
\text { Comm. } \\
\text { appro }^{\text {val }} \text { in } \\
\text { Feb. } 99\end{array}$ & Not informed \\
\hline Portable computers, & & $\begin{array}{c}\text { Under } \\
\text { development } \\
\text { in Feb. } 99\end{array}$ & Not informed \\
\hline Cat bed & NL & $\begin{array}{l}\text { Suspended in } \\
\text { Feb. } 99\end{array}$ & $\begin{array}{l}\text { - Lack of scientific information to back proposed criteria in } 96 . \\
\text { - Low-priority dossier according to the Commission, given its predictably low environmental impact. }\end{array}$ \\
\hline $\begin{array}{c}\text { Hair sprays } \\
\text { (conditioners, } \\
\text { shampoo, } \\
\text { deodorant, hair } \\
\text { dressing products) }\end{array}$ & UK & $\begin{array}{l}\text { Suspended in } \\
\text { Feb. } 99\end{array}$ & $\begin{array}{l}\text { - Opposition of the industry: negative marketing impact for non-ecolabeled products; opposition to criteria } \\
\text { giving the advantage to pump-sprays (no final demand). } \\
\text { - Crossed bargaining as regards industry's involvement in other dossiers: shampoo, deodorant, cosmetic } \\
\text { products are blocked by the industry, as long as a solution on the hairspray dossier has not been reached. } \\
\text { - National issues: EU firms versus one US firm implanted in the UK. } \\
\text { - The preliminary study for devising the criteria has been completed for shampoo had been completed, but } \\
\text { the work has later on been suspended. }\end{array}$ \\
\hline $\begin{array}{c}\text { Floor cleaning- } \\
\text { products, Sanitary- } \\
\text { cleaning products, } \\
\text { Rubbish bags, } \\
\text { Converted paper } \\
\text { products }\end{array}$ & \begin{tabular}{|l} 
(not \\
inform \\
ed)
\end{tabular} & $\begin{array}{l}\text { Suspended in } \\
\text { Feb. } 99\end{array}$ & Study has been completed on these groups; the reasons for work suspension have not been informed. \\
\hline Ceramic tiles & $\mathrm{I}$ & Suspended & Commission's refusal of Italian criteria. Product_having too long of a life-cycle. \\
\hline
\end{tabular}

Source: Nadaï 1996a, 1996b, and EU, 1999.

*Member State in charge of the preliminary proposal of criteria and heading of the devising of the criteria.

** During the first negotiation of the criteria (revised criteria).

\section{Bibliography}

Nadaï, A. (1996a) The negotiation of paint and varnishes ecolabelling criteria, Survey (in French language) for the French Energy Agency ADEME, CERNA: Ecoles des Mines de Paris-

Nadaï, A. (1996b), The EU processes of evaluation and signaling to the market of the products environmental performances: current issues and prospects, Survey (in French language) for the French Energy Agency (ADEME), the National Centre of Scientific Research (CNRS) and a group of Industrialists (Firms members of "Club CRIN-Environnement"), CERNA: Ecole des Mines de Paris.

Nadaï A. (1998a), Concurrence sur la qualification environnementale des produits, Revue d'Economie Industrielle, 83, 197-212.

Darby M. and Karni E. (1973), Free competition and the optimal amount of fraud, Journal of Law and Economics, 16, 67-88.

EU, 1999, EU Commission's ecolabel homepage "http://europa.eu.int/comm/dg11/ecolabel/prodgr.htm”.

Wolinsky, A. (1995), Competition in a market for credence goods, Journal of Institutional and Theoretical Economics, 151-(1), 117-131. 